Check for updates

New York, USA

Cite this as: BMJ 2020;370:m2851 http://dx.doi.org/10.1136/bmj.m2851 Published: 15 July 2020

\section{Covid-19: Doctors in France report case of baby infected in utero}

\author{
Janice Hopkins Tanne
}

French doctors have reported the case of a 23 year old woman in the last weeks of her first pregnancy who was hospitalised with covid-19 in March and gave birth by caesarean section to a baby boy found to have the infection in what appears to be the first documented case of transplacental transmission of the virus.

The doctors say, in their report in Nature Communications, ${ }^{1}$ that their findings confirm that covid-19 causes maternal viremia, placental infection, and neonatal viremia. Previously, doctors had thought that some babies had contracted the virus in the womb but could not rule out the chance that the baby had been infected during or shortly after delivery.

The mother was hospitalised in March after two days with a fever and severe cough. Real time polymerase chain reaction detected the $\mathrm{E}$ and $\mathrm{S}$ genes of the SARS-CoV-2 in her blood and in nasopharyngeal and vaginal swabs. Three days later, the fetus developed tachycardia and a caesarean section was performed "with intact amniotic membranes, in full isolation, and under general anaesthesia because of maternal respiratory symptoms. Clear amniotic fluid was collected prior to rupture of membranes, during caesarean section, and tested positive for both the E and S genes," the doctors reported.

The baby had an Apgar score of 4 and was intubated (because of the general anaesthesia) and transferred in full isolation to the neonatal intensive care unit in a negative pressure room. Before he was extubated, blood and bronchoalveolar fluid were collected. Both were positive for the $\mathrm{E}$ and $\mathrm{S}$ genes of the virus.

Three days after birth the baby developed irritability, difficulty feeding, muscle weakness, and opisthotonos-neurological signs that the infection had crossed the placenta. The virus was detected in the baby's blood. Cerebrospinal fluid did not show covid-19 or other possible causes but magnetic resonance imaging scans showed gliosis, a sign of infection.

The baby slowly improved over the next few days and was discharged after 18 days. Follow-up at nearly two months showed neurological improvement and normal growth.

"The good news is that the baby very much recovered. The baby is fine," corresponding author Daniele De Luca told the Guardian. ${ }^{2} \mathrm{He}$ is medical director of paediatrics and neonatal clinical care at Antoine Béclère Hospital in Paris.

Real-time polymerase chain reaction testing of the placenta, which showed signs of inflammation, was positive for both the $\mathrm{E}$ and $\mathrm{S}$ genes of covid-19.

The report noted that "Both E and S genes of SARS-CoV-2 were found in each and every specimen. The viral load is much higher in the placental tissue than in amniotic fluid or maternal blood: this suggests the presence of the virus in placental cells, which is consistent with findings of inflammation seen at histological examination."

De Luca told the Guardian that pregnant women should be reassured, saying, "Clinicians must be aware that this may happen. It's not common, that's for sure, but it may happen and it must be considered in the clinical workout.”

Vivanti AJ, Vauloup-Fellous C, Prevot S, et al. Transplacental transmission of SARS-CoV-2 infection. Nat Commun2020;11:3572doi: 10.1038/s41467-020-17436-6. Sample I. Baby boy infected with coronavirus in womb. Guardian. 14July 2020. www.theguardian.com/science/2020/ju/14/baby-boy-infected-with-coronavirusin-womb. 